\title{
Anti-peptide antibodies in the diagnosis of malaria
}

\author{
J P Dean Goldring ${ }^{*}$, Ramona Hurdayal, David Choveaux \\ From Parasite to Prevention: Advances in the understanding of malaria \\ Edinburgh, UK. 20-22 October 2010
}

Lactate dehydrogenase is one of the antigens targeted in lateral flow immunochromatographic rapid diagnostic tests for the diagnosis of malaria. Unique diagnostic peptide targets based on the respective amino-acid sequences to differentiate between $P$. falciparum and $P$. vivax lactate dehydrogenase were chosen, synthesized and coupled to rabbit albumin carrier. Anti-peptide antibodies were raised in chickens against the peptides and against each of the recombinant proteins and affinity purified. An antibody against a common epitope detected recombinant $P$. falciparum, $P$. vivax and $P$. yoelii and native $P$. falciparum and $P$. vivax protein lactate dehydrogenase. Antibodies against species specific lactate dehydrogenase epitopes differentiated between $P$. falciparum and $P$. vivax lactate dehydrogenase. The study supports an anti-peptide antibody approach for the design of malaria diagnostic reagents.

Published: 20 October 2010

Submit your next manuscript to BioMed Central and take full advantage of:

- Convenient online submission

- Thorough peer review

- No space constraints or color figure charges

- Immediate publication on acceptance

- Inclusion in PubMed, CAS, Scopus and Google Scholar

- Research which is freely available for redistribution

Submit your manuscript at www.biomedcentral.com/submit
() Biomed Central 